UDC 19.01.09

\author{
${ }^{1}$ Michael Brown, ${ }^{2}$ Galiya Ibrayeva \\ ${ }^{1} \mathrm{PhD}$ Emeritus professor, University of Wyoming Laramie, Wyoming, USA \\ e-mail: mrbrown@uwyo.edu \\ ${ }^{2}$ Professor, doctor of political science al-Farabi Kazakh National University, Almaty, Kazakhstan \\ e-mail: galiya.Ibrayeva@kaznu.kz
}

\title{
Why Study Journalism: Motivation of Future Kazakh Journalists
}

\begin{abstract}
This paper is part of a large international research project: Journalism Students across the Globe: Professionalization, Identity and Challenges in a Changing Environment. Journalism education in Kazakhstan, like elsewhere, needs to account for changes in the information environment. This project examines the motives to study journalism by students from Kazakhstan. Do today's student motivations reflect an understanding of new media with its text, images, infographics, data, and new genres; and how should a journalist combine knowledge of the various media fields? Study of the motivations of Kazakh students in this context is important for both national interests and aligning Kazakh journalism education with international expectations. An online survey used open-ended questions to elicit replies. Questions focused on career opportunities for journalism students, aspects of education that motivate students and whether a university degree is necessary to become a professional journalist. Findings were compared to historical journalistic motivations in Kazakhstan. Students now are driven by different motives. In the past journalistic education was a building block for a career in politics or writing. Now students know various fields of journalism and what the fields offer. Journalism students prefer TV, but a high percentage also prefer the increasingly important online environment. The formula for modern education in the age of information and new technologies is an ongoing systematic process of learning for both educators and students, driven by motivations that are important not only within the walls of universities, but in everyday life.
\end{abstract}

Key words: journalism education, motivation, new media, state independence, Kazakhstan.

${ }^{1}$ Мишель Браун, ${ }^{2}$ Ғалия Ибраева

${ }^{1} \mathrm{PhD}$, профессор, Вайоминг университеті Вайоминг, АҚШ, e-mail: mrbrown@uwyo.edu ${ }^{2}$ Профессор, саяси ғылымдарының докторы Әл-Фараби атындағы ҚазҰУ, Алматы, Қазақстан e-mail: galiya.Ibrayeva@kaznu.kz

\section{Неліктен журналистиканы зерттеу болпшақ Қазахстандық журналистерді насихаттау}

Бұл мақалада үлкен халықаралық зерттеу жобасы жарыққа шығады: жахандық журналистика: кәсібилік, сәйкестендіру және өзгеретін ортадағы проблемалар . Журналисттік білім беру Қазақстандағы ақпараттың қалай болғанына қарамастан, білім беруді жетілдіруді қажет етеді. Бұл жобада қазақстандық студенттердің журналистиканы үйренудің мотивтері талқыланады. Күнделікті мотивтерден оқушыларға олардың жаңа мәтіндерді, суреттерді, инфографиканы, деректерді, жаңа жанрларды түсінуді және БАҚ-нің әртүрлі саласындағы білімді журналист қалай біріктіруді қарастырады . Бұл тұрғыда қазақстандық студенттердің мотивациясын зерттеу ұлттық мүдде үшін де, қазақстандық журналистік білімнің халықаралық үміттерге сәйкес келуі үшін де маңызды. Онлайн-сауалнама жауап алу үшін ашық сұрақтарды пайдаланды. Студенттік журналистердің мансаптық мүмкіндіктері, оқушыларды ынталандыратын білім беру аспектілері және кәсіби журналист болу үшін жоғары білім алу қажеттілігі туралы сұрақтар қойылған. Нәтижелер тарихи призма арқылы қарастырылды. Студенттер әрқашан әртүрлі мотивтермен қозғалыста болады. Бұрын журналистік білім саясатта немесе жазу саласында мансапқа негіз болатын. Енді студенттер-журналистер телевидениені жақсы көреді, бірақ үлкен пайызы онлайн ортаны маңызды деп санайды. Ақпараттық және жаңа технологиялар заманындағы қазіргі білім формуласы мұғалімдер мен оқушылар үшін ғана емес, сонымен қатар күнделікті өмірде университеттер қабырғаларында маңызды рөл атқаратын үздіксіз жүйелі процесс болып табылады.

Түйін сөз: журналистік білім, мотивация, жаңа медиа, мемлекеттік егемендік, Қазақстан. 


\begin{abstract}
${ }^{1}$ Мишель Браун, ${ }^{2}$ Галия Ибраева
${ }^{1} \mathrm{PhD}$, professor, Вайомингский университет, штат Вайоминг, США, e-mail: mrbrown@uwyo.edu ${ }^{2}$ Профессор, доктор политических наук, Казахский национальный университет имени аль-Фараби, Алматы, Казахстан, e-mail: galiya.Ibrayeva@kaznu.kz
\end{abstract}

\title{
Зачем изучать журналистику: мотивация будущих журналистов
}

\begin{abstract}
Эта статья является частью большого международного исследовательского проекта: Глобальная журналистика: профессионализация, идентичность и проблемы в меняющейся среде. Журналистское образование в Казахстане, как и везде, должно учитывать изменения в информационной среде. В этом проекте рассматриваются мотивы изучения журналистики студентами из Казахстана. Отражают ли сегодняшние мотивы студента понимание новых медиа с их текстом, изображениями, инфографикой, данными и новыми жанрами; и как журналист должен объединять знания различных областей СМИ? Изучение мотивации казахстанских студентов в этом контексте важно как для национальных интересов, так и для приведения казахстанского журналистского образования в соответствии с международными ожиданиями.

В онлайн-опросе использовались открытые вопросы для получения ответов. Вопросы были сосредоточены на возможностях карьерного роста студентов-журналистов, аспектах образования, которые мотивируют студентов, и на том, необходимо ли высшее образование, чтобы стать профессиональным журналистом. Результаты были рассмотрены сквозь историческую призму. Студенты всегда движимы разными мотивами. В прошлом журналистское образование было основой для карьеры в политике или писательстве. Теперь студенты-журналисты предпочитают телевидение, но большой процент считает более важной онлайн-среду. Формула современного образования в век информации и новых технологий - это непрерывный систематический процесс обучения как для преподавателей, так и для студентов, движимых мотивами, которые важны не только в стенах университетов, но и в повседневной жизни.
\end{abstract}

Ключевые слова: журналистское образование, мотивация, новые медиа, государственная независимость, Казахстан.

Introduction. The first program for journalism education was introduced in Kazakhstan in 1934 at Al-Farabi Kazakh National University (KazNU). Today it is the largest school of journalism in Kazakhstan with about 700 students studying in three languages: Kazakh, Russian and English, through baccalaureate, master, and doctoral level education. There are about 22 public and private universities offering degrees in journalism in Kazakhstan. Today's students are the first generation born and raised in an independent Kazakhstan, free of the ideology of Marxism-Leninism and Communist Party standards. In addition to gaining independence, these young people are emerging into a world of new technologies, the Internet and private independent media. After Kazakhstan joined the Bologna Convention in 2003, thousands of students participated in exchange programs with European and American universities and further continued graduate studies at the world's top universities with the support of a state scholarship program called, "Bolashak." Understanding the motivations of these students as they train for media professions is important for understanding journalistic expectations in Kazakhstan and where they fit into the larger world view of journalism students.

This article presents the results of a survey conducted in Kazakhstan as part of the global survey project, Journalism Students Across the Globe: Professionalization, Identity and Challenges in a Changing Environment. Journalism students from 42 countries participated in a global survey, including two universities from the Central Asia: American University of Central Asia (Kyrgyzstan) and alFarabi Kazakh National University (Kazakhstan). The global survey was initiated and organized by Claudia Mellado, University of Santiago (Chile) and Folker Hanusch, Queensland University of Technology (Australia). KazNU was chosen to participate in the project because of the large number of journalism majors, and because it is one of the oldest journalism education institution in the region as successor to the Communist Institute of Journalism established in 1934. As Kazakhstan grows as a new nation its journalism students face new challenges associated with a new media environment as well as those associated with a new nation.

Literature review. The motives for choosing a degree in journalism have been shaped by the mentality of the Kazakh nation for several centuries, including a close association with Russia. It is important to examine the motivations for those students who seek to be journalists in this new media environment, and today's media environment was shaped by Kazakhstan's past. There were three periods that formed the foundation for the 
journalism profession in Kazakhstan. The first period occurred in the late 1800s and early 1900s with the founding of first the newspapers in Kazakh and Russian languages. The second period is from 1917 to 1991 when Kazakhstan was influenced by the Soviet Union. The third period occurs from 1991 to the present once Kazakhstan became independent.

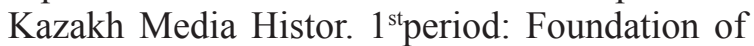
the first newspapers in Kazakh language.

The first Kazakh newspapers, Turkestan Ualayatynyn Gazeti (1870-1882) and Dala Ualayatynyn Gazeti (1888-1902), were established in Kazakhstan in the second half of the 19th century in the national outskirts of tsarist Russia. The independent newspapers Kazakh Gazeti (1907), Serke (1907), and the magazine Aikap (19111915) were created at the beginning of the struggle against the tsarist autocracy (Subhanberdina, Dautov 1995). The first journalists became public figures who enlightened readers. Early journalists Mukhamedzhan Seralin, Akhmet Baitursynov, and Myrzhakyp Dulatov established the primary motive for the profession of journalist during the first phase. Their mission was to be patriotic. Being a journalist in Kazakhstan meant more than searching for, preparing, and disseminating information. Kazakh educators promoted the role of journalism as a defender of national interests and national values. Therefore, any event was presented from the perspective of its impact on national values. As a result today's journalists continue to evaluate the benefits, burdens and general impact of events on the nation with more vigor than the usual "Five W's - What, Who, When, Where, Why." For Kazakhs journalism is not just a profession but a national duty. Therefore, Kazakh journalism is closely related to politics. The journalist was, and is, expected to be a public figure and a patriot. (Abdiraman, 2015) Journalists were the spiritual and moral leaders of the Kazakh nation: Abai, Shokan Valikhanov and Ibrahim Altynsarin. The journalism of the country is a chronicle, and the historical memory and practice of journalism was shaped by these progressive sons of Kazakh people who established the national mass media.

$2^{\text {nd }}$ period: Journalism in the Soviet Union. The first Soviet newspapers opened after the Bolshevik Revolution of 1917. In May 1923 there were 24 newspapers in Kazakhstan, 17 of which were in Russian, 6 in Kazakh, and one in Tatar, as well as eight magazines, including one in the Kazakh language. Only six out of one hundred people working in journalism had higher education. The staff was mainly composed of talented workers and correspondents from rural areas. Every year several communists were sent to study at the State Institute of Journalism in Moscow (Bekhozhin, 1964; Imashev S, 1961; Ashenova, 2016). In 1930 there were 41 sent to Moscow, by May of 1931 the number went up to 55. There were special newspapers for the cooperative peasantry and in 1931 there were 37 new newspapers created in different regions of Kazakhstan. Regional newspapers played an increasing role in the collectivization process. The intensive development of a system to train workers and rural area correspondents took place during this period and they joined the staff of rural and regional newspapers. In 1934 the Kazakh Communist Institute of Journalism was established on Press Day. In the 1930s there were 345 newspapers, 307 broadcasting centers and 57 thousand radio receiving sets in Kazakhstan. A reduction in the number of newspapers occurred during the Patriotic War of 1941-1945 when journalists were sent to the front where 10 front-line and more than 10 divisional newspapers were published, two of them in the Kazakh language (Ashenova, 2016).

In the postwar period, the development of agriculture and the Virgin Land Campaign required further development of regional press. By 1958 there were 13 national, 33 regional, 11 urban and 206 rural newspapers and magazines. During these years national and local television started broadcasting in the country. In addition, print and radio offered new forms of journalism. The Union of Journalists of the USSR was created and hosted the first Congress of Journalists of Kazakhstan. The journalism of Kazakhstan during this period was already formed as a system of mass media and propaganda based on Soviet media models. During these years, the fight against "bourgeois-nationalist views" in literature, art and science was expressed in the press. The press opposed the original folk culture and criticized the national epos and performance of improvised poets (akyns) as an incitement of ideology for the "feudal elite," which was a crime. The independent opinion of the representatives of the Kazakh society, which did not align with the party's ideology, became the basis for the political persecution of many scholars and writers, including scholars like Professor Ermukhan Bekmakhanov. His book Kazakhstan in the 20's-40's of $21^{\text {st }}$ Century was published in 1947. E. Bekmakhanov was accused of "bourgeois ultranationalism" and sentenced to 25 years in jail in 1952. He was later rehabilitated in 1954. Soviet authorities pursued the hard line of the party leadership which suppressed all manifestations of opposition. All media outlets were under total 
control and censorship. During the "Cold War" from the beginning of 1950s through the1980s there was confrontation between bourgeois and socialist journalism. The media formed an image of the ideological enemy, preparing negative content about the "bourgeois world." Kazakh media followed the ideology set by the party in Moscow and complied with its requirements.

At the same time, despite the specific conditions under which journalism developed in Kazakhstan, much was accomplished regarding cultural education of the audience and growing professional skills of media workers. The increase in the number of newspapers, the emergence of radio, television, and documentary films required an increase in the number of journalists. The first journalism department was established in the Philological Department of the Kazakh State University after Kirov (now al-Farabi Kazakh National University). In the mid-1960s the School of Journalism was established and began to educate Kazakh journalists. Each year no more than 100 students, including 50 students studying in Kazakhstan language and 50 students studying in Russian language were admitted to the program. More than 50 percent were recruited from the industry, already working in the media, and the rest after high school. Since the School of Journalism was formed within the Philological Department, the orientation of training for a long time remained philological (Nemecek et.al., 2011). The faculty prepared journalists, editors, writers, taught the theory of literature and addressed all philological disciplines. For Kazakh journalists education was an important step into the world of writers who enjoyed great popularity and respect as the best representatives of a knowledge-based society, a kind of "standards of wisdom, honesty and Kazakh philosophy." One of the opposition journalists Muftakh N. wrote: "Conduct a sociological survey among students of the School of Journalism and you will see that 90 out of 100 of Kazakhs came here just because they write poems and think of the journalist diploma not as an entrance ticket to the world of journalism, but as an entrance into the world of writers." (Muftakh, 1996). The transition to the third period in the development of Kazakhstan journalism openly began in 1985 after the proclamation restructuring the Soviet Union. This led to the gradual easing of censorship and strict ideological control, the development of publicity, the expansion of freedom for journalistic activities, and the formation of media independent from Soviet control. This was not an uncontested change. The party was still strong and Kazakh journalists were subject to great pressure during the December uprising in 1986 in which a group of people protested against communist power. It was sparked by a decision of the General Secretary of Central Committee of the Communist Party of the Soviet Union, S. Gorbachev, to discharge Dinmuhamed Kunayev from the position of First Secretary of the Communist Party and appoint a man who had no relation to Kazakhstan. December events in Kazakhstan were among the first protest meetings in Soviet Union. However, the effect was a rise in national consciousness, intensified social and political movement in society, with the press, journalists, radio and television becoming the main force of democratic transformation.

$3^{\text {rd }}$ period: Independent Kazakhstan. The role of the mass media in Kazakhstan changed dramatically after independence from the Soviet Union in 1991. There was the formation of democratic values and principles, and a growing democratic political culture. In addition, journalism helped achieve a national consolidation of citizens and introduced global values. On December 16, 1991 the law "On the State Independence of the Republic of Kazakhstan" was enacted, which legalized the emergence of an independent state of Kazakhstan. Media in Kazakhstan began to practice free of censorship, while the Communist Party of the Soviet Union and the Communist Party of Kazakhstan were terminating their activity. The first independent newspapers, radio and television stations were established. Media were divided into state supported and commercial operations. The format of broadcasting and the topics of interest changed becoming less ideological and more diverse.The program of journalism education at universities also changed. Schools of journalism, which previously existed only at KazNU, opened in all regions of Kazakhstan, and their numbers increased to 50. The system of admission also changed providing more opportunities to receive a degree in journalism. Earlier educational programs were coordinated with the leading universities of Russia, now the content of journalistic education began to depend on Ministry of Education and Science of Kazakhstan with the exception of KazNU which, as a research university, was given more autonomy over its own decisions about educational programs.

Modern Media Environment in Kazakhstan. Today Kazakhstan has a diverse media environment. In 2019 there were 3328 media, in which 1800 newspapers registered $(83,8 \%)$ are nongovernmental) and 990 magazines $(65 \%$ are nongovernmental, and 33\% are state owned). There were 128 registered TV stations. Only two are state owned: JSC Regional Television and Radio 
Company (RTRC) "Kazakhstan" and JSC Agency "Khabar." The structure of RTRC "Kazakhstan" includes four TV channels: "Kazakhstan" (100\% in the Kazakh language) and its 19 regional branches, "Balapan" for children, "Kazsport" and "First Channel Eurasia." JSC Agency "Khabar" includes TV channels "Khabar," "24 KZ," "Bilim zhane Madeniet" (knowledge and culture) and "Kazakh TV." Regional state channels include "Zhetysu,"
"Almaty," "CTC," "9 Arna," "Didar," "Focus" and "Municipal channel." There were 70 radio channels, four offered by the state. The state operates two online information agencies: inform.kz, bnews. $\mathrm{kz}$. The state also operates a news aggregator in the Kazakh language at baq.kz and an information portal called Strategy2050.kz. (Dannye, 2019). The number of media outlets available in 2013, 2014, 2019 can be seen in Table 1:

Table 1 - Number of media outlets by year*.

\begin{tabular}{|c|c|c|c|}
\hline Mass Media & Year 2013 & Year 2014 & Year 2019 \\
\hline Print media & 1881 & 1898 & 1800 \\
\hline Newspapers & 1362 & 1367 & 990 \\
\hline Magazines & 519 & 531 & 198 \\
\hline Electronic media & 219 & 260 & 128 \\
\hline TV channels & 71 & 95 & 340 \\
\hline Radio stations & 49 & 58 & 9 \\
\hline News agencies & 64 & 8 & 122 \\
\hline Satellite broadcasting operators & 7 & 99 & 340 \\
\hline Cable TV operators & * Note: developed by the author & \\
\hline
\end{tabular}

Online journalism is actively developing. Social networks have become a competitive source of information compared to traditional media and are second in popularity to television. If 10 years ago only $4 \%$ of the population of Kazakhstan had access to the Internet, at present it is around $70 \%$, or 12 million users. The most popular networks are VKontakte at 2.7 million users, Classmates at 2 million, My World with 1.6 million, Facebook at 0.6 million, and Twitter at 0.3 million, as well as Instagram and Kazakh-social networks (Ruzanov, 2015).

Journalism Education. A study of students' attitudes towards their future profession is important knowledge for higher education. Motives for choice of degree in creative fields, such as journalism were determined by such traditional factors as "the diversity and fascination by the profession, its creative nature, the opportunity to communicate with interesting people, to be aware of the events, feelings and opinions of people." (Korkonosenko, 2016). To what extent have motives changed when innovative technology and new media emerge and content is not just text but images, infographics, data, and new genres; and when should a journalist combine knowledge of the various fields of media and communication?

Considering the questions of motives, the author also relies on the works of Russian scholars who are interested in journalistic motives (Vartanova E., McQuail, D., Trappel, J., 2015; Dzyaloshinsky, 2013 \& 2011; Kolesnichenko, 2015). Another important source is the research of Professor Nico Drok (2011) of the Windesheim University of Applied Science and Leader of the European Competence Profile Project of the European Journalism Training Association (EJTA). Particularly, he notes that in the context of technological and economic changes in social development all 60 journalism schools from 25 European countries who are members of the EJTA demonstrate consensus on the future of the core competencies of the journalist. This position is consistent with the Declaration of Principles of the World Journalism Education Council (WJEC) adopted in Singapore (2007), that "Journalism is a global activity. Student-journalists must understand 
that despite the political and cultural differences, they share common professional values and goals with colleagues from other countries. Therefore, journalism education should provide students with first-hand knowledge about the practice of journalism in other countries" (World Journalism Education Congress, 2016).

A survey of more than four thousand journalism students in Australia, Brazil, Chile, Mexico, South Africa, Spain, Switzerland and the United States showed that the motivation of students to obtain a journalism degree and their future plans and expectations depend on national contexts of journalism education. For more reliable recent statistics in years 2015-2016 universities of Australia and Chile organized a new large-scale study, covering almost all continents of the globe. Kazakhstan was included in the project for the first time. (Hanusch \& Mellado, 2015; Hanush \& Mellado, 2014; Hallin.\& Mellado, 2017).

The Brazilian scholars Becker and de Castro (2014) discuss the importance of providing opportunities for students to think about journalism as a form of knowledge and produce more creative and critical news, which is important in preparing them as future professionals. The research of Dailey and Rocky (2016) points to the importance of intellectual and creative processes of journalism for the future. Norwegian scientist Morten Kronstad (2014) found value in the way journalism students who worked as journalists prior to becoming students use this experience in their education. The emphasis is on how students in undergraduate programs in the school of journalism use their experience and practical knowledge along with educational activities, and how this knowledge is expressed. The research studied students who started out as practicing journalists and it showed that practice and education is a strong combination for journalists and journalism education.

Pilar Sánchez-García (2016) conducted quantitative and qualitative content analysis of 66 educational undergraduate programs before and after the implementation of the European Higher Education Area in 35 Spanish universities that offer a degree in journalism. The research shows the process of adaptation of the first phase of the EHEA standards in the new media environment. The study reveals four directions: the map of education program of bachelor in journalism, changes in curriculum content, the overall succession or renewal of curriculum, and specialized education for new media. The main conclusion is that the gradual change of educational trends in Spain emphasizes improving practice-specific training and a reduction of interdisciplinary-theoretical content. The study also shows that there is a restriction on the inclusion of mandatory courses about new technologies used in new professions.

Elias Machado and Tattiana Teixeira (2016) explain that journalism schools still follow the standard pedagogical model of teaching. The authors argue that the integration of teaching and applied research is particularly important for overcoming the current crisis of the media which face outdated business models created in the previous century. One of the main conclusions of the study is that a lack of cooperation between universities and the media industry should give way to a hybrid model of learning that includes multidisciplinary applied research projects aimed at developing new formats, graphic languages, methods, processes and prototypes of content for different production platforms.

Scholars suggest that journalism is changing and requires new educational models that value critical and creative thinking while providing practical experience and strong links to industry. There is no doubt that changes to the media influence the ways students perceive the profession and their motivations for pursuing a degree. At the same time, journalism education is adjusting to the needs of today's journalism practice. Kazakhstan is in a particularly unique position of recently developing a national and commercial media. Study of the motivations of Kazakh students to pursue journalism in this context is important for both national interests and aligning Kazakh journalism education with international expectations.

Material and Methods. Organizers of the project "Journalism Students across the Globe: Professionalization, Identity and Challenges in a Changing Environment" developed the methodology for this project. The leading scientists Folker Hanusch of Queensland University of Technology and Claudia Mellado of the University of Santiago de Chile developed and shared research methodology, developed a survey as the research instrument, and monitored the data collection. The survey instrument was tested in prior research and found to be both reliable and valid (Hanush, 2013). This article reports on the collection of data in Kazakhstan.

This research is focused on determining reasons and motivations of young people for studying journalism. The demographic segment chosen for this study were students of journalism faculty in KazNU. An online tool was created and administered this survey. Open-ended questions 
were chosen in order to elicit honest and genuine replies. Some of the most pertinent questions of the study focused on career opportunities journalism students hope to have, aspects of university education that motivate students to study and whether a university degree is necessary to become a professional journalist

While the overall survey focused on a number of important topics, this article presents the findings of the survey that focused on student's motivation for studying journalism from their perspective as future journalists. The focus of this research considers the following objectives:

1. to compare the motivation for choosing the profession of journalism in different periods of the country's development;

2. to show the influence of gender on the choice of profession;

3. to show the influence and role of the faculty of journalism in choosing to work in the field of journalism.

Subjects. The survey was translated from English to Kazakh and Russian languages and was distributed among undergraduate and graduate students of the School of Journalism. In total 334 students participated in the survey, representing about $50 \%$ of the total number of journalism students at the school. There were 35 questions in the questionnaire which was posted by the author using the online survey service www.surveymonkey.com. In this article the authors examine only one aspect of the study "motivation for studying journalism from the perspective of future journalists" of Kazakhstan.

Results and Discussion. In Kazakhstan 334 students of the School of Journalism at KazNU participated in the survey: $84.76 \%$ bachelor students and $15.24 \%$ graduate students (master's degree). The year of education of the undergraduate students: $1^{\text {st }}$ year $-25.38 \%, 2^{\text {nd }}$ year $-25,68 \%, 3^{\text {rd }}$ year $31.12 \%, 4^{\text {th }}$ year $-17.82 \%$. Ages ranged from 18 to 34 years. Gender was $29.09 \%$ male and $70.91 \%$ female. The questionnaire was designed to compare different answers in order to understand the true opinion of students on a particular issue. For this study questions №1,6, 13, and 14 of the master survey were used to identify the motives of future journalists.

Question №1 asked about the preferred field of work after study, "If you could choose, in which field would you like to work when you finish your studies?" Only $57.36 \%$ of the students surveyed chose to work in the field of journalism, $22.22 \%$ prefer to work in public relations and advertising, $8.11 \%$ - teaching and research, $11.71 \%$ - to create their own business, to be producers, directors (see Figure 1). There were also those who wished to change profession and to become lawyers or enroll in a different program (Fig.1):

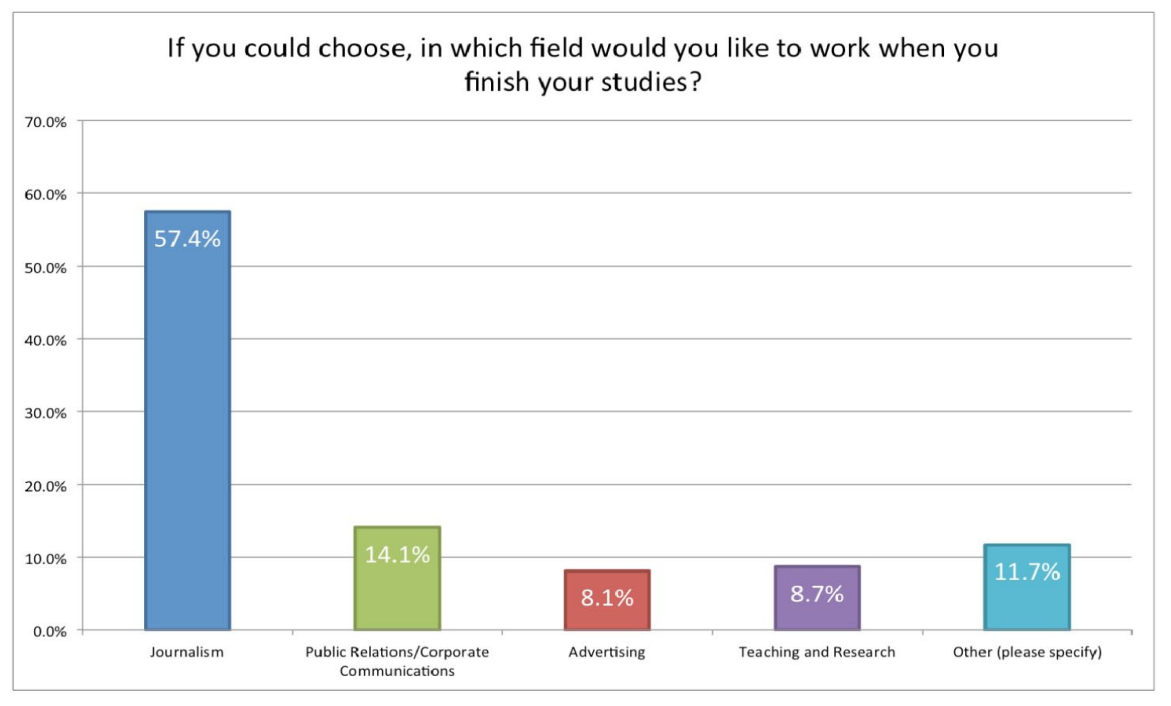

Figure 1. Percent of students represented by desired profession *Note: developed by the author

Question № 6 is about the motives for choosing the degree. Students were offered about twenty motive activities in the field of journalism which could meet the ambitions of young, entrepreneurial and talented persons. Each motive had five degrees of evaluation increasing from the category "Not 
important at all" to "Extremely important." All motives can be grouped by topics such as personalcareer, the opportunity to demonstrate power, protection of state interests and common persons and others. Question № 6 asked, "Please rate the following aspects in terms of the extent to which they motivated you to study your degree." (see Table 2). Interpretations of the results can vary and bring different conclusions, therefore this table is presented in detail (Tabl.2):

Table 2. Motivation for pursuing degree*

\begin{tabular}{|c|c|c|c|c|c|c|c|}
\hline Answer option & $\begin{array}{c}\text { Not important } \\
\text { at all }\end{array}$ & $\begin{array}{c}\text { Little } \\
\text { important }\end{array}$ & $\begin{array}{c}\text { Some } \\
\text { what important }\end{array}$ & $\begin{array}{c}\text { Very } \\
\text { important }\end{array}$ & $\begin{array}{l}\text { Externaly } \\
\text { important }\end{array}$ & $\begin{array}{l}\text { Rating } \\
\text { Average }\end{array}$ & $\begin{array}{c}\text { Response } \\
\text { Count }\end{array}$ \\
\hline The opportunity to travel & $6 \%$ & $9 \%$ & $39 \%$ & $13 \%$ & $33 \%$ & 3.56 & 329 \\
\hline $\begin{array}{l}\text { The possibility of } \\
\text { being famous }\end{array}$ & $10 \%$ & $14 \%$ & $36 \%$ & $18 \%$ & $22 \%$ & 3.28 & 326 \\
\hline To help in nation-building & $3 \%$ & $12 \%$ & $35 \%$ & $25 \%$ & $26 \%$ & 3.58 & 329 \\
\hline The varied and lively work & $3 \%$ & $9 \%$ & $31 \%$ & $27 \%$ & $31 \%$ & 3.74 & 329 \\
\hline $\begin{array}{l}\text { The chance to } \\
\text { influence public affairs }\end{array}$ & $3 \%$ & $9 \%$ & $30 \%$ & $29 \%$ & $28 \%$ & 3.71 & 326 \\
\hline $\begin{array}{l}\text { To work for freedom } \\
\text { and democracy }\end{array}$ & $12 \%$ & $14 \%$ & $33 \%$ & $19 \%$ & $22 \%$ & 3.24 & 326 \\
\hline The pleasure of writing & $6 \%$ & $12 \%$ & $33 \%$ & $21 \%$ & $28 \%$ & 3.52 & 326 \\
\hline $\begin{array}{l}\text { The chance to help people in } \\
\text { their everyday life }\end{array}$ & $5 \%$ & $10 \%$ & $37 \%$ & $26 \%$ & $22 \%$ & 3.5 & 329 \\
\hline $\begin{array}{l}\text { The amount of money } \\
\text { one can earn }\end{array}$ & $5 \%$ & $9 \%$ & $37 \%$ & $24 \%$ & $25 \%$ & 3.56 & 326 \\
\hline $\begin{array}{l}\text { To hold people in } \\
\text { power accountable }\end{array}$ & $9 \%$ & $16 \%$ & $32 \%$ & $25 \%$ & $18 \%$ & 3.29 & 327 \\
\hline To get a secure job & $7 \%$ & $9 \%$ & $36 \%$ & $22 \%$ & $26 \%$ & 3.52 & 327 \\
\hline $\begin{array}{l}\text { The amount of } \\
\text { autonomy one has }\end{array}$ & $8 \%$ & $18 \%$ & $40 \%$ & $18 \%$ & $16 \%$ & 3.17 & 326 \\
\hline To fight injustice & $6 \%$ & $14 \%$ & $37 \%$ & $24 \%$ & $19 \%$ & 3.36 & 326 \\
\hline My talent for journalism & $5 \%$ & $10 \%$ & $32 \%$ & $24 \%$ & $28 \%$ & 3.61 & 325 \\
\hline To be able to be creative & $3 \%$ & $9 \%$ & $33 \%$ & $27 \%$ & $27 \%$ & 3.66 & 327 \\
\hline $\begin{array}{l}\text { The prestige of journalism as a } \\
\text { profession }\end{array}$ & $4 \%$ & $16 \%$ & $34 \%$ & $21 \%$ & $25 \%$ & 3.47 & 324 \\
\hline $\begin{array}{l}\text { The chance to meet } \\
\text { different people }\end{array}$ & $3 \%$ & $6 \%$ & $31 \%$ & $28 \%$ & $32 \%$ & 3.79 & 325 \\
\hline The dynamic lifestyle & $4 \%$ & $6 \%$ & $31 \%$ & $28 \%$ & $30 \%$ & 3.74 & 325 \\
\hline $\begin{array}{c}\text { To help the } \\
\text { government achieve its } \\
\text { goals for } \\
\text { national development }\end{array}$ & $4 \%$ & $13 \%$ & $35 \%$ & $22 \%$ & $26 \%$ & 3.55 & 327 \\
\hline
\end{tabular}

First, students rated motivation on a 5-point scale from "not important at all" to "extremely important." The data in Table 3 shows that most students chose the central response option «somewhat important.» The highest percentage of "extremely important" responses indicated that some students chose 
journalism to travel (33\%) and meet different people $(32 \%)$, for the varied and lively work $(31 \%)$, and a dynamic life $(30 \%)$. These four motivating factors were extremely important for over $30 \%$ percent of respondents. The "ratings average" indicates the overall importance of each motivating factor. The most important factors included three of the four motivations rated above as "extremely important." These were to meet people (3.79) and have a dynamic life (3.74) with work that is varied and lively (3.74). Also, journalism students were motivated by the potential to influence public affair (3.71) and the opportunity to be creative (3.66). In addition to the important motivations were those of lesser concern. The least important motivation was autonomy (3.17). The next lowest included the promotion of freedom and democracy (3.24), being famous (3.24), and holding the powerful accountable (3.29). Although these were among the lowest ratings, more than $40 \%$ still considered these motivations "very important" or "extremely important." These findings indicate that students want an interactive, dynamic, and varied professional life. The opportunity to become involved in public affairs is important even though this may not apply directly to the promotion of freedom and democracy or to holding those in power accountable. Still, all of the ratings averages were above 3.0 indicating a variety of motivations are important reasons for students to choose journalism careers.

Question №13 is somewhat provocative, asking whether it is necessary to study journalism and communication at the university level in order to be a good journalist. Most students found education important with $53.66 \%$ of the students "Very much agree" that journalism and communication should be studied at university level, "Somewhat agree" - 25.91\%, "Somewhat disagree" - 12.80\%, "Very much disagree" $-7.62 \%$. The results show that more than half of the students think that it is necessary to study journalism and communication at university level in order to be a good journalist. This figure rises to almost $80 \%$ with those who "Somewhat agree."

Question № 14 relates to the previous question and addressed those students who disagreed that it is necessary to study journalism at the university level and asked them about their opinion. About 51 detailed responses were received. Several key elements were present in the responses to why an education is unnecessary. These included whether the individual was already a journalist $(23.5 \%$ of responses), practical training in the field (17.6\%), and an understanding of journalism (13.7\%). Students believed that "experience and practice are essential," "a talent to express one's thoughts cannot be taught," "a student has to study for four years at university, however it is necessary to have experience to become a journalist, and therefore studying for two years at university should be enough" There is an opinion that "if you choose to work on television, but you have unappealing look and a terrible diction, regardless of the high degree, you will not be able to present content on TV program. The talent of the journalist - is from God!" While some students believe that experience and natural talent are more important than education, this supports the overall claim that journalism education, along with theory, should include good training in the field.

The results of the study help us understand what motivates young students to be journalists and how journalism education can help students reach their goals of becoming professionals. This study provides a good overview of the motivations of students but also provides an opportunity to compare the motivation for choosing the profession of a journalist at different periods of the country's development. If we compare the motivation for choosing the profession in the last century to the current century, we can see similarities and differences.

The first phase of Kazakh journalism featured the founders who brought the media and journalism education to Kazakhstan. Today's educators in Kazakhstan also face a developing media and a changing media environment. They are reconstituting journalism degrees to meet the needs of today's students and today's media. A trend of our time is the interest to work not only in print media, but also in online media, where there is a convergence of the creative process. This requires the ability to write texts, to take video and photos, comment and communicate with your audience. This form of communication is appealing to students and is more frequently required by the media. This study provides some guidance to educators by pointing to the value of practical experience and various motivating factors

The motivations of students share similarities and differences with the position of the leaders of Alash Orda party with regard to the mission and role of the journalist, which is being a patriot of your country. Like Alash Orda, today's students are motivated by an opportunity to influence public affairs. And while fighting injustice and helping the government achieve national development goals was not a top motivation for today's students like it was for Alash Orda, these were still important motivations. As the $2^{\text {nd }}$ phase of journalism developed under communism Alash Orda changed 
as they were absorbed into communism and the role of the journalist became more ideological under Soviet control. Journalists were not allowed much autonomy and today's students were least motivated by the need for autonomy or the desire to promote freedom and democracy. In today's $3^{\text {rd }}$ phase of Kazakh journalism, students are most motivated by the lifestyle of journalism, the opportunity to interact with others, and to influence public affairs. The challenge for journalism educators in Kazakhstan is to develop education programs that account for student motivation while at the same time account for today's new media and Kazakhstan's young and developing media as a relatively new country.

There was an important correlation between gender and the choice of profession. The study showed that more than 70 percent of students at the Journalism School are women. This is the trend not only in Kazakhstan but also around the world. In Soviet times, women accounted only for 3 to 4 percent. The School of Journalism admitted students mostly with work experience in newspapers after serving in the Soviet Army. Therefore, only a small percentage, including women, were high school graduates, and admittance required potential students to show their works published in newspapers. The result was that most early students were male. While more females were admitted during Soviet times, the increase in female enrollment was significant after the fall of the Soviet Union. It is interesting to note that nearly $71 \%$ of the survey respondents were female, which fits the profile of KazNU journalism students, but also indicates a female influence in the choice of motivations to be a journalist. The motivation to gain fame and popularity was not the most important, but more than half of the students dreamed of a career as a TV host or a travel reporter.

Another aspect of the study was to show the influence and role of the School of Journalism in the motivation of journalism students. One critical observation was the need to connect with the media and provide experience. The School of Journalism at KazNU motivates students by inviting prominent journalists and practitioners to conduct workshops and organize training in the form of case studies which makes the learning process more engaging and entertaining. In addition, the School of Journalism has its own high-quality television studio, radio studio, and special equipment for magazines and newspapers production with illustrations.

\section{Conclusion}

Students at KazNU study the media and start working with the media from the first year of the school, and this combination has successfully allowed them to secure employment by the time they graduate from university. Students of the School of Journalism of KazNU represent a new generation of young journalists of a sovereign state and are capable of independently and realistically assessing their motives for choosing journalism as a profession.

Findings of this research can be summarized by following conclusions: First, from analyzing the history of journalism in Kazakhstan it is evident that students are now driven by different motives than they were 50 years ago. In the 1960's journalistic education was considered a building block for a career in writing which was a popular occupation at that time. Now students have a clear idea of the various fields of journalism and in which they would like to work. The primary mass medium that journalism students prefer is TV, but a high percentage of students prefer to work in the increasingly important online environment. This new online trend in journalism in Kazakhstan provides another way for journalists to promote the flow of Kazakhlanguage and Russian language information through social networks which offer new ways to affect the public consciousness and shape Kazakhstan's media environment.

Moreover, the romantic and active life of a journalist appeals to today's students, but they clearly understand that behind the facade of a profession there is hard and complex work, and they value journalistic activities and potential rewards of the profession. They express readiness to develop and operate their country's information field, its national values and cultural priorities. The motivations of students represent those of a majority of female students. It is evident that journalism in Kazakhstan is aligned with global trends in gender politics, the majority of journalism students are female. These students challenged the system of journalism education while evaluating the importance of journalism education in the country and provided valuable information to guide journalism education. At the same time, they understand the value of education for professional development and self-improvement. This suggests that the formula for modern education in the age of information and new technologies is a constant and systematic process of learning for both educators and students, driven by motivations that are important not only within the walls of universities, but in everyday life. 


\section{References}

Abdiraman E. (2015). V chem problema kazahskoy zhurnalistiki. Obzor kazahoyazychnoy pressy. Retrieved from https://radiotochka.kz/12104--v-chem-problema-kazahskoy-zhurnalistiki-obzor-kazahoyazychnoy-pressy-ot-radiotochki.html Now are close.

Ashenova S. (2016). Istorya kazahskoi zhurnalistiki. Uchebnoe posobie. Retrieved from http:// http://psu.kz/arm/upload/ umk/172172.doc.

Becker, B., de Castro, L. (2014). Innovative Writing of the Twenty-First Century: Multimedia Journalism and Education. Journal of Applied Journalism \& Media Studies, 3 (3), pp. 335-353.

Bekhozhin H.N. (1964) Puti razvitiya kazakhskoi pechati (1860-1930 гг.) A., - 72 str.

Bekmahanov E. B. (1946) Kazakhstan s 20-30 gg. XIX veka. Monografiya. - Alma-Ata, 1946. - 782 str.

Dannye (2019, 28 January). Kolichestvo zaregistrirovannyh SMI v Kazakhstane. Ministerstvo informacii I kommunikacii Respubliki Kazkahnstan. Retrieved from http://mic.gov.kz/ru/pages/kolichestvo-zaregistrirovannyh-smi-v-kazahstane

Drok, N. (2011). The Shift of Professional Competences in Journalism Education. Retrieved from http://www.mediascope. $\mathrm{ru} /$ ?q=node/859

Dzyaloshinsky, I. M. (2011). Ten Mortal Sins of Journalism in the Perspective of to-be Journalists. Retrieved from http://www. mediascope.ru/?q=node/952

Hallin, Daniel and Mellado, Claudia (2017). Serving Consumers, Citizens, or Elites: Democratic Roles of Journalism in Chilean Newspapers and Television News. The International Journal of Press/Politics 1-20.

Imashev S. (1961) Zarozhdeniye kommunisticheskoi pechati v Kazakhstane. -Alma-Ata, -Kazgosizdat.- $112 \mathrm{~s}$.

Hanush, F. \& Mellado, C. (2014). Journalism Students' Professional Views in Eight Countries: The Role of Motivations, Education, and Gender. //International Journal of Communication, 8, pp. 1156-1173.

Hanusch, F., Mellado, C., Boshoff, P., Humanes, M., de León, S., Pereira, F., Ramírez, M., Sergio Roses, S., Subervi F., Wyss, V., \& Yez, L. (2014). Journalism Students' Motivations and Expectations of Their Work in Comparative Perspective. // Journalism \& Mass Communication Educator, 70 (2), 2: pp. 141-160.

Hanusch, F. (2013) Moulding Industry's Image: Journalism Education's Impact on student's professional Views. //Media International Australia, 146, pp. 48-59.

Journalism students across the Globe (2015). Retrieved from http://www.jstudentsproject.org/p/network.html

Kolesnichenko, A.V. (2015). Russian Journalists and Their Work: Exploring Motivation and Satisfaction. Retrieved from http:// www.mediascope.ru/?q=node/2046

Korkonosenko S. G. red. (2016). Sociologiya zhurnalistiki: uchebnik dly bakalavrov/ - 2- izd., perebot.i dop.- M.:Izd-vo Yurait, $421 \mathrm{c}$.

Kronstad, M. (2014). Using the Gut Feeling - Making Sense of Practical Knowledge in Journalism Education. Journal of Media Practice, 15 (3), pp. 176-189.

Machado, E. and Teixeira, T. (2016). Innovation as an Essential Part of Journalism Education in Contemporary Societies. Journal of Applied Journalism \& Media Studies, 5 (1), pp. 103-116.

Mellado, Claudia; Humanes, María Luisa; Scherman, Andrés; Ovando, Auska (2018). Do digital platforms really make a difference in content? //Mapping journalistic role performance in Chilean print and online news. Journalism , 1-20.

Muftakh N. (1996). Dozhivem do ponedelnika, 1996. - February. pg. 4. Now are close.

Nemecek, M., Ketterer, S., Ibrayeva, G. \& Los, S. (2011). Journalism Education and Professional Training in Kazakhstan: From the Soviet Era to Independence (pp. 217-232) in Eric Freedman \& Richard Shafer, eds., After the Czars and Commissars: Journalism in Authoritarian Post-Soviet Central Asia. Retrieved from http://www.jstor.org/stable/10.14321/j.ctt7ztd46

Rocky, D. (2016). The Path to Professionalism: Common Core, Competency- Based Education and the Needs of Today's Journalist. Journalism Education Today, 49 (4), pp 9-47.

Ruzanov A. (2015, April 20) Samye populyrnye seti v mire, Rossii I Kazakhstane. Retrieved from http://www.brif.kz/blog/?p=2634

Sánchez-García, P. (2016). The Effects of the First Phase of the EHEA in Journalism Education in Spain: More Specialized and Practical Training. Communication \& Society, 29 (1), pp. 125-142.

Subhanberdina U., Dautov C., Nurgaliev R. (1995) Aikap. Almaty: Kazakh enciklopediyasy.- 368 bet. (kaz)

Vartanova, E., McQuail, D., Trappel, J. (2015). European Media in Crisis. In Trappel, J., Steemers, J., \& Thomass, B (Ed.), Values, Risks and Policies, pp. XX-XX. New York \& London: Routledge Taylor \& Francis Group.

World Journalism Education Congress (2016). Auckland, New Zealand July 2016. Retrieved from http://www.aejmc.org/home/ events/wje 